\title{
SOME PARTICULARITIES OF THE COMMISSION CONTRACT, AS REGULATED BY THE CIVIL CODE
}

\author{
Ioan SCHIAU ${ }^{1}$
}

\begin{abstract}
This paper aims to throw a light on some particularities of the commission contract as it is presently regulated by the Civil Code, as a species of the mandate contract (without representation). Although the commission contract is well known and often met in the trade, there are still some features that deserve consideration, mainly due to the approach used by the lawmaker in order to translate this contract from the Commercial Code to the Civil Code. It is noteworthy that, while no legal obligational relationship is established between the principal and the third party, sometimes the effects of the contract concluded by the commissioner with the third party are placed directly in the patrimony of the principal, as an apparent exception to the contract's relativity principle.
\end{abstract}

Key words: commission, object, writ of replevin, subrogation, receivable, right to claim.

\section{Introduction}

The commission contract, initially regulated by Articles 405 et seq. of the Commercial Code, has borrowed new clothes and moved under the cupola of the new Civil Code, becoming part of the contracts that are the common realm of the unitary private law.

Born as a special form of the mandate without representation, the commission contract allows the commissioner to act in its own name but on the account of the principal and, by that, constitutes a convenient instrument for the occultation of the identity of the principal, in relation with the third-party and, furthermore, for concealment of the fact that the commissioner is acting on behalf of somebody else.

The Romanian legal term is "comisionar". This term is sometimes translated as "commission agent" but the author opted for "commissioner", term which is similar with the Romanian one. Consequently, the commissioner is eliminating the risk of being removed from the contractual mechanism, through the third party avoiding the commissioner and contacting directly the principal.

While the advantages and structure of the commission contract are well known to traders and to the legal environment, the relocation of this contract from the Commercial Code to the Civil Code has produced various deviations and alterations, some of them being the subject of this paper's brief examination.

\footnotetext{
${ }^{1}$ Transilvania University of Braşov, Faculty of Law, ioan.schiau@unitbv.ro
} 


\section{Object and Nature of the Contract}

According to its initial definition, provided by Article 505 C. Com., the object of contract of commission is the dealing of commercial businesses, done by the commissioner on the account of the principal.

Although such definition may appear somehow vague, it has the merit that it allows the commissioner to perform, on the account of the principal, a wide range of acts and activities, starting with identifying potential contractors, negotiating with them the terms and conditions of the contracts and, finally, within the limits of its powers, concluding contracts in its own name but on the accounts of the principal.

While the definition of the commission contract does not limit the extent of the commercial businesses that the commissioner may be instructed to deal for the principal, the norms of the Commercial Code (Articles 406 - 412) were mainly making reference to the sale or purchase transactions and, only twice, to "operations", a term that may indicate a wider array of dealings.

Aiming to bring more clarity and precision to the commission contract, Article 2043 of the Civil Code states that the commission contract is the mandate that has as object the acquisition or sale of goods or the provision of services on the account of the principal and in the name of the commissioner that is acting professionally, for a remuneration (named "commission").

The inspiration source for this definition seems to be Article 1731 of the Italian Civil Code that defines the commission as being a mandate having as object the purchase or the sale of goods on the account of the principal and in the name of the commissioner.

The first thing to mention here is that the commission contract is a mandate, that is, according to Article 2009 of the Civil Code, the contract by which a party is obliging itself to conclude one or more juridical acts on the account of the other party.

It seems that the definition assumed by the Civil Code is broader than the one fostered by the Commercial code, since it is considering not only sale operations but, also, a large area of provision of services. While the Commercial Code specifically provided that the object of the contract is a commercial one ("commercial businesses"), the Civil Code is using an apparent neutral approach, but the activities circumscribed to the object of the contract are similar to those indicated by art. 8 para. (2) of Law. 71/2011 for application of the Civil Code as replacing the concept of "commercial acts and deeds", used by the Commercial Code, i.e. "activities of commerce and provision of services".

More, by stating that the commissioner is acting professionally, Article 2043 is indicating that this person is a professional (in Romanian language: profesionist), a term applied to those persons that are systematically operating an organized business (in Romanian language: întreprindere), consisting in acts of production, administration and sales of goods as well as provision of services (Article 3 of the Civil Code).

All these clues are pointing to a commercial activity, demonstrating that the commission contract is not designed for classic civil acts but for commercial operations that are performed in order to produce a profit. In other terms, the commission contract is a commercial contract used by professionals. 
There is only a problem with the legal terminology used by the lawmaker. According to Article 2043 of Civil Code, the main object of the commission contract is the power given to the commissioner to conclude acquisition or sale transactions. Or the term "acquisition" is not defined and it used rarely in the Civil Code, mainly with the signification of acquirement by any means. Moreover, the current use of the term "acquisition" means, primarily, procurement of goods not only through purchase but by any other legal mean as labour, trade, donation, time barring of an obligation, etc.

Nevertheless, it is questionable if the lawmaker meant, by using the term "acquisition", to extend the commissioner's possibilities to acquire a good on the account of the principal (by accepting grants, providing labour services, accepting change of goods or promoting legal actions to sanction the elapse of the legal limitation period a. s. o.) or we are facing a simple carelessness of the lawmaker that is inadequately using lay terms instead of legal defined terms, as the purchase of goods.

To answer that question, it is noteworthy that the examination of the rest of the text dedicated to the commission contract shows that the lawmaker repeatedly used the term "purchase" instead of "acquisition" and this may be a clear enough sign that the last term is used by accident.

Therefore, in an extended definition, that is cumulating the essentials items provided for by Article 2009 of the Civil Code with those of Article 2043 of the Civil Code, the commission contract is to be viewed as the contract by which the commissioner, acting professionally, undertakes to conclude, in its own name but on the account of the principal, one or several legal acts having as object the purchase or sale of goods or the provision of services, in exchange of a remuneration, called commission.

\section{The Effects of the Contract}

Article 2045 of the Civil Code states that the third party that is contracting with the commissioner is liable directly towards the latter for the assumed obligations. Since the commission contract is a mandate, it is also regulated by Article 2040 of the Civil Code, asserting that the third parties have no legal relation with the principal. Both these statements, in line with the principle of contract's relativity (that is, the contract is producing effects only between the signatories/parties), are reinforcing the idea that the commissioner, based upon the powers allocated to him through the commission contract, is signing contracts with third parties in its own name and that these contracts produce effects only between the commissioner and the contracting third party (Chirică, 2018, p. 25). As usual, there are some exceptions to the rule.

\subsection{Actions of the Principal against the Third Party}

According to Article 2046 of the Civil Code, if the third party fails to perform its obligations, assumed toward the commissioner, the principal may exercise the actions born out of the contract concluded with the third party by subrogating itself in the rights of the commissioner, based on the assignment made by the commissioner in regard of this right to claim. 
The lawmaker is amalgamating here two different legal institutions, making reference to both the subrogation and the assignment of rights that have different meanings, conditions and effects. The subrogation, according to Article 1593 of the Civil Code, means that the person that is paying instead of the debtor will be subrogated (substituted) in the creditor's rights. The creditor may consent to the subrogation, whenever is paid by a third party, by transferring to the payer the rights held against the debtor. This may be the hypothesis embraced by Article 2046 of the Civil Code, mention being made that, nevertheless, the creditor (the commissioner) does not receive any payment from the principal, the "subrogation" being made with no consideration being paid by the principal. Therefore, this is an improper subrogation and the term is inappropriately used by the lawmaker. In that respect, one may note that a proper subrogation in a similar case is provided by Article 401 of the Swiss Civil Code of Obligations, where, if the agent acting on the principal's behalf acquires claims in his own name against third parties, such claims pass to the principal provided he has fulfilled all his obligations towards the agent under the agency relationship.

On the other hand, the assignment of the right to claim is an accessory of the assignment of receivables that is transferring to the beneficiary all the rights regarding the receivable, including all guarantees and rights to claim. Therefore, the substitution of the commissioner by the principal is made based on a voluntary assignment of the receivables of the commissioner against the contracting third party, without consideration being paid by the principal, since this one is the real owner of the goods, while the assignment of the right to claim is only auxiliary to such assignment of receivables.

Anyhow, this is only an apparent exception to the above-mentioned rule, since the principal is acting against the third party as a result of the assignment by the commissioner of its own rights, derived from the contract concluded with the third party. The commissioner has a legal obligation to assign those rights at principal's first request, otherwise being liable for the damages caused to the principal by its default.

\subsection{Actions of the Principal against the Commissioner.}

According to Article 2041 of the Civil Code, regarding the mandate without representation and which, absent contrary provisions, is also applicable to the commission contract, the principal may revendicate, claim (replevin) the movable property acquired on its account by the commissioner that was acting in its own name. Replevin is an action by which a plaintiff having a right in personal property which is claimed to be wrongfully taken or detained by the defendant seeks to recover possession of the property and sometimes to obtain damages for the wrongful detention. Retrieved from: https://www.merriam-webster.com/dictionary/replevin.

The revendication claim or writ of replevin (in Romanian language: acțiunea in revendicare - Article 562 et seq. of the Civil Code) is the court action or claim that the owner of a good may take against the person that possesses the good or against another person that is holding the good without a valid title. In order to give value to the provisions of Article 2041 we need to confer the position of plaintiff to the principal 
while the defendant is the commissioner; consequently, the right given to the principal to claim the goods that the commissioner has acquired on its account, qualifies the principal as being the legal owner of those goods. In other words, the lawmaker presumes that the movable property is acquired by the commissioner not only on the account of the principal, but directly in its name (Afrăsinei, 2013, Comments 2041). That is to say that, although there are no legal relations between the principal and the third party, the indirect or imperfect representation granted by the principal to the commissioner is the legal link that explains how and why the proprietary rights over the movable assets pass directly from the third party to the principal.

This is an effect of the mandate without representation that reverberates in the commission area also and entitles one to assert that the acts concluded by the commissioner, in its own name but on the account of the principal, regarding the transfer of property upon movable property, generate effects that are located directly in the principal's patrimony; this deviation from the relativity of contracts' principle does not constitute an infringement of the rule that the third parties have no legal relation with the principal, but an effect of the mandate relationship, which empowers the commissioner to act on account of the principal.

\subsection{Actions of the Commissioner's Personal Creditors}

Article 2042 of the Civil Code states that the commissioner's creditors are not allowed to enforce their claims against the goods acquired by the commissioner in its own name but on the principal's account, provided that the commission contract has a certified date that is prior to any protective, precautionary or enforcement measures taken by the creditor.

The explanation consists, of course, in the fact that these goods, acquired on the account of the principal, are not property of the commissioner, which is holding them as a temporary custodian, on behalf of the principal, the real owner and dominus negotii. But, to grant full force to this legal presumption, the law asks the parties of the commission contract to take a further step and to provide a certified date of their contract, as to prove that their agreement was concluded before any protective or enforcement measures being taken.

On the other hand, by construing the above quoted provisions in the light of the per a contrario arguments, it results that the commissioner's creditors may enforce their claim on these goods, if the commission contract does not bear a certified date. As strange as this conclusion appears, it means that this provision of Article 2042 of the Civil Code has to be construed in agreement with the provisions of Article 2044 of the Civil Code, that states that the commission contract written form has only a probative value, unless the law provides otherwise. Or, Article 2042 of the Civil Code provides otherwise, asking the written form and the certified date of the contract in order to produce the effect of blocking the protective or enforcement measure taken by the creditors.

Anyhow, the possibility that the creditors (absent the certified date) may enforce their claim against the goods held by the commissioner on account of the principal, indicates another deviation from the rule that there is no legal relation between the principal and 
the third parties (moreover, when the third parties are the persons contracting with the commissioner as a consequence of the powers conferred to it by the principal).

In such a case of enforcement of the creditors' claims against the principal's goods held by the commissioner, the principal is entitled to intervene in the process and claim a personal interest, as the real owner of the goods.

\subsection{Replacement of Third Party by the Commissioner}

According to Article 2050 of the Civil Code, when the powers granted to the commissioner regard the sale or purchase of securities or other listed goods, the commissioner may supply itself, directly, the goods that he has to buy or to retain itself the goods that he has to sell, at the price indicated by the principal or at the market price and under certain conditions.

This is an important derogation from the rule stating that the commissioner has to conclude legal acts with third parties, in his name but on the principal's account. Actually, the commissioner is replacing the third parties and the commission contract is entwinned with a sale or purchase contract concluded between the same parties (principal and commissioner), with exclusion of any third party.

Such a mechanism is valid if the goods have a known market price or are listed on a stock or commodity exchange, if the powers granted to the commissioner do not expressly prohibit such sale or purchase made by the commissioner replacing the third party and if the commissioner immediately notifies the principal that it will deliver its own goods or will retain the goods entrusted for sale to third parties. All these conditions are meant to confer transparency and accountability to the commissioner operations, in order to protect the principal's legitimate interests.

\section{References}

Afrăsinei, M. (2013) (Colectiv). Noul Cod Civil comentat [New Civil Code commented] Hamangiu. Retrieved from: https://idrept.ro/DocumentView.aspx? Documentld=33018676

Chirică, D. (2018). Probleme controversate privitoare la contractul de mandat [Controversial issues regarding the mandate contract] Juridice.ro. Retrieved from: https://www.juridice.ro/essentials/1903/probleme-controversate-privitoare-lacontractul-de-mandat. 